\begin{tabular}{|c|c|}
\hline 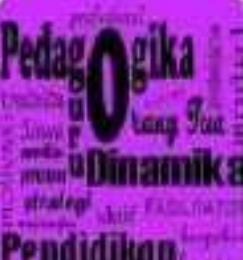 & $\begin{array}{l}\text { Pedagogika: Jurnal Pedagogik dan Dinamika Pendidikan } \\
\text { P-ISSN2252-6676 E-ISSN2746-184X, Volume.9, No. 1, Apri2021 } \\
\text { doi: https://doi.org/10.30598/pedagogikavol9issue1year2021 } \\
\text { https://ojs3.unpatti.ac.id/index.php/pedagodika, } \\
\text { email: jurnalpedagogika@gmail.com }\end{array}$ \\
\hline
\end{tabular}

\title{
PENGARUH MODEL PEMBELAJARAN TREFFINGER TERHADAP HASIL BELAJAR SISWA PADA MATERI BANGUN DATAR KELAS IV MI SALMAN AL-FARISI LIANG Nurul Annisa Ali ${ }^{*}$, Johannis Takaria ${ }^{2}$, Nessy Pattimukay ${ }^{3}$ \\ Program Studi PGSD Univesitas Pattimura Ambon ${ }^{1,2,3}$ email:nurulannisa024@gmail.com
}

Abstrak, Pembelajaran matematika dapat dikatakan berhasil jika siswa dapat memahami konsep, penguasaan materi, serta hasil akhir yang diperoleh siswa telah mencapai Kriteria Ketuntasan Maksimum (KKM). Terkait dengan hal tersebut tujuan dari penilitian ini adalah untuk mengetahui pengaruh model pembelajaran Treffinger terhadap hasil belajar siswa pada materi bangun datar kelas IV yang berlokasi pada MI Salman Al-Farisi Liang, dan tipe penelitian Quasi Eksperiment dengan desain penelitian One Group Pretest-Posttest design. Penelitian ini melibatkan seluruh siswa kelas IV MI Salman Al-Farisi Liang yang berjumlah 15 orang siswa, untuk menganalisis peningkatan hasil belajar siswa digunakan $\mathrm{N}$-gain. Hasil penelitian menunjukan bahwa ada pengaruh model pembelajaran Treffinger terhadap peningkatan hasil belajar siswa, dengan hasil perhitungan $N$-gain diperoleh hasil belajar siswa dengan menggunakan model pembelajaran Treffinger 73,3\% siswa dengan peningkatan hasil belajar matematika berada pada kategori tinggi, 20\% siswa berada pada kategori sedang, dan 6,6\% siswa berada pada kategori rendah.

Keywords : Model Pembelajaran Treffinger, Hasil Belajar Siswa, Matematika SD.

\section{The Influence of the Treffinger Learning Model on Student Learning Outcomes in Class IV Flat Building Material at MI Salman Al-Farisi Liang Nurul Annisa Ali ${ }^{1}$, J. Takaria ${ }^{2}$, N. Pattimukay ${ }^{3}$}

\begin{abstract}
Mathematics learning can be successful if the students can understand the concept, theory, and can get the assment standard of mathematics learning. Related to this, the purpose of this study is to determine the effect of the Treffinger learning model on student learning outcomes in class IV flat shape material located at MI Salman Al-Farisi Liang, and the type of Quasi Experiment research with the One Group Pretest-Posttest design. This research involved all students in grade IV MI Salman Al-Farisi Liang, totaling 15 students, to analyze the increase in student learning outcomes using $\mathrm{N}$-gain. The results showed that there was an effect of the Treffinger learning model on improving student learning outcomes, with the results of the Ngain calculation, the learning outcomes of students using the Treffinger learning model were 73.3\% of students with an increase in mathematics learning outcomes were in the high category, $20 \%$ of students were at medium category, and $6.6 \%$ of students are in the low category.
\end{abstract}

Keywords: Treffinger Learning Model, Student Learning Outcomes, Mathematics in Grade School 


\section{PENDAHULUAN}

Matematika diperlukan untuk membekali siswa menjadi pelajar yang mandiri dan mampu mengatasi permasalahan yang muncul dalam kehidupan. Oleh karena itu, pelaksanaan pembelajaran Matematika tidak cukup hanya memberikan informasi berupa teori atau konsep yang bersifat hafalan saja, perlu berorientasi pada pengembangan keterampilan-keterampilan yang dibutuhkan dalam pemecahan masalah (Azizah dkk, 2018). Dalam pembelajaran matematika di Sekolah Dasar siswa dituntut untuk berpikir kritis dan kreatif dalam suatu pemecahan masalah matematis terkait dengan kehidupan nyata siswa.

Namun pada kenyataannya bagi banyak siswa, mata pelajaran matematika menjadi sesuatu objek yang menakutkan. Mereka berpandangan bahwa matematika sulit untuk dimengerti karena terkesan abstrak, sehingga menimbulkan kecemasan sebelum mengikuti pembelajaran di kelas. Scarpello (2007; Abdul Gafoor \& Kurukkan, 2015) kecemasan matematis menyebabkan banyak individu menghindar dari aktivitas dengan matematika. Verhoeven (2006; Takaria, 2018; Takaria, 2019) adanya phobia terhadap matematika berakibat kurangnya minat untuk mempelajari matematika.

Pembelajaran matematika hendaknya menghadirkan permasalahan terkait kehidupan nyata siswa dengan menggunakan benda-benda kongkrit, sehingga pembelajaran matematika menjadi bermakna dan pandangan siswa terhadap sulitnya matematika dapat diminimalisir. Salah satu penyebab rendahnya kemampuan matematika siswa adalah kemampuan komunikasi matematis (Ferdianto, 2015).

Observasi awal yang dilakukan terhadap mata pelajaran matematika khususnya pada materi bangun datar ditemukan bahwa pemahaman siswa masih pada kategori rendah. Hal ini dikarenakan kurangnya pemahaman konsep, kurangnya peguasaan materi, dan pembelajaran masih berpusat pada guru (teacher center). Sehingga siswa kurang aktif dalam pembelajaran di kelas. Diharapkan juga guru mendaknya menerapkan penggunaan model pembelajaran kreatif yang dapat memicu siswa untuk mengeksplorasi ide mereka. Terkait permasalahan yang dihadapi dalam upaya peningkatan hasil belajar matematika siswa, maka salah satu model pembelajaran yang dapat memfasilitasi belajar matematika siswa adalah model pembelajaran Treffinger.

Model Treffinger diperkenalkan Donald J. Treffinger pada tahun 1980. Donald J. Treffinger adalah presiden di Center of Creative Learning, IncSarasota, Florida. "Model ini dikembangkan sebagai upaya dalam membangkitkan belajar kreatif" (Treffinger, 1980. Sari \& Putra 2015). Model Treffinger diharapkan dapat memicu siswa untuk berpikir kreatif dalam pemecahan masalah matematika.

Model pembelajaran Treffinger merupakan cara untuk belajar kreatif, melalui tingkatan yang dimulai dengan unsur-unsur dasar ke fungsi-fungsi kreatif yang lebih kompleks. Langkah-langkah pembelajaran disusun dalam tiga tingkatan berisi teknikteknik belajar kreatif. Tingkat I, teknik dasar berupa fungsi divergen, teknik kreatif yang digunakan adalah pertanyaan terbuka dan sumbang saran. Tingkat II, proses berpikir dan perasaan majemuk, teknik kreatif yang digunakan adalah analogi. Tingkat III, keterlibatan dalam tantangan nyata. Teknik kreatif yang digunakan adalah pemecahan masalah kreatif (Treffinger, 1980; Wirahayu dkk, 2017).

Model pembelajaran Treffinger merupakan model pembelajaran kreatif, yang melibatkan kemampuan kognitif dan afektif. Yang memiliki tiga tingkatan langkahlangkah pembelajaran, sehingga mendorong siswa untuk berpikir kreatif dalam mengeksplorasi ide. Siswa dituntut untuk dapat memecahkan permasalahan matematika, khususnya pada materi bangun datar.

Mengacu pada deskripsi latar belakang yang diuraikan, maka penelitian ini terfokus dalam menganalisis pengaruh penggunaan model pembelajaran Treffinger terhadap hasil belajar siswa pada materi bangun datar di kelas IV MI Salman Al-Farisi 
Liang Kabupaten Maluku Tengah.

\section{METODOLOGI}

Metode penelitian yang digunakan adalah metode eksperimen semu (quasi eksperiment), dengan desain one group pretest-posttest. Desain ini adalah suatu rancangan pretest dan posttest yang dilaksananakan pada satu kelompok saja tanpa pembanding (Ajie, dkk. 2013). Tujuannya untuk mengetahui pengaruh dari model pembelajaran Treffinger terhadap hasil belajar matematika siswa pada materi bangun datar kelas IV MI Salman Al-Farisi Liang.

\section{Instrumen dan Teknik Pengumpulan Data}

Instrumen yang digunakan untuk melihat pengaruh model pembelajaran Treffinger terhadap hasil belajar siswa adalah: (1) tes, adapun tes yang dilakukan berupa pretest dan posttest yang terdiri dari 5 soal essay; (2) lembar observasi, lembar observasi yang digunakan adalah lembar observasi untuk mengamati aktifitas guru selama mengajar sesuai dengan RPP yang telah dibuat dan lembar observasi untuk mengamati aktivitas siswa selama proses pembelajaran berlangsung.

\section{Analisis Instrumen}

Sebelum melakukan pengukuran menggunakan instrumen tes dalam penelitian maka perlu dilakukan analisis intrumen. Validitas instrumen dan realibitas merupakan alanalis instrumen yang digunakan dalam penelitian ini. Tujuannya untuk mengetahui tingkat validitas dan reliabelitas data. Perhitungan validitas dan reliabilitas dianalisis menggunakan program statistik SPSS 23.0 for windows.

\section{Teknik Analisis Data}

Untuk analisis data dalam melihat pengaruh model pembelajaran Treffinger terhadap hasil belajar siswa pada materi bangun datar kelas IV, maka data pretest dan posttest sebelum dianalisis perlu dilakukan uji asumsi yaitu uji normalita dan homogenitas.

1. Uji Normalitas

Uji normalitas bertujuan untuk menentukan apakah kedua sampel berasal berdistribusi normal atau tidak dengan menggunakan Kolmogorov-Smirnov. Jika nilai sig. > 0,05 maka data normal.

2. Uji Homogenitas

Uji Homogenitas data dilakukan untuk mengetahui data variabel bebas $\mathrm{X}$ (model pembelajaran Treffinger) dan Variabel terikat Y (peningkatan hasil belajar siswa) berasal dari varian yang homogen atau tidak. Perhitungan homogenitas menggunakan rumus Levene, dimana nilai Sig. $>\alpha$ maka varian homogen.

Langkah selanjutnya didesain hipotesis penelitian dan selanjutnya dilakukan pengujian dengan menggunakan uji t-independent jika asumsi terpenuhi. Namun jika asumsi tidak terpenuhi maka dilakukan pengujian nonparametrik dengan jenis uji Wilcoxon. Uji t-dependent digunakan untuk menguji hipotesis antara variable bebas $\mathrm{X}$ (model pembelajaran Treffinger) dan Variabel terikat Y (peningkatan hasil belajar siswa) dengan menggunakan perhitungan SPSS 23.0 For Windows. Untuk mengetahui pengaruh model pembelajaran Treffinger terhadap hasil belajar siswa pada materi bangun datar kelas IV MIT Al-Anshor digunakan rumus:

$$
\mathrm{t}=\frac{\delta}{\mathrm{SD} \delta / \sqrt{\mathrm{N}}}
$$


Dalam melihat peningkatan hasil belajar matematika siswa, maka digunakan $\mathrm{N}$-gain dengan rumus (Hage, 1998 ;Takaria, 2018) :

$$
\mathrm{N}-\text { gain }=\frac{\text { posttest score }- \text { pretest score }}{\text { maximum possible score }- \text { pretest score }}
$$

Selanjutnya hasil perhitungan (N-gain) yang diperoleh, dikonfirmasikan dengan kriteria gain ternormalisasi pada Tabel 1 .

Tabel 1. Kriteria N-gain

\begin{tabular}{|c|c|}
\hline $\mathbf{N}$-gain $(<\mathbf{g}>)$ & Klasifikasi \\
\hline $\mathrm{g} \geq 0,70$ & Tinggi \\
\hline $0,30 \leq \mathrm{g}<0,70$ & Sedang \\
\hline $\mathrm{g}<0,30$ & Rendah \\
\hline
\end{tabular}

\section{HASIL PENELITIAN DAN PEMBAHASAN}

\section{Hasil Penelitian}

Pengumpulan data hasil belajar siswa dilakukan dengan cara pemeberian pretest dan posttest kepada siswa, data pretest dan posttest diklasifikasikan pada Tabel 2 dan Tabel 3.

Tabel 2 Klasifikasi Hasil Pretest Siswa

\begin{tabular}{|c|c|c|c|}
\hline Hasil Pretest & $\begin{array}{c}\text { Jumlah } \\
\text { Siswa }\end{array}$ & Presentase & Kategori \\
\hline $90-100$ & 0 & $0 \%$ & Sangat Tinggi \\
\hline $75-89$ & 0 & $0 \%$ & Tinggi \\
\hline $60-74$ & 2 & $13,3 \%$ & Sedang \\
\hline $40-59$ & 9 & $60 \%$ & Rendah \\
\hline $0-39$ & 1 & $6,6 \%$ & Sangat Rendah \\
\hline Total & 15 & $100 \%$ & \\
\hline
\end{tabular}

Tabel 3. Klasifikasi Hasil Postest Siswa

\begin{tabular}{|c|c|c|c|}
\hline Hasil Posttest & mlah Siswa & Presentase & Kategori \\
\hline $90-100$ & 11 & $73,3 \%$ & Sangat Tinggi \\
\hline $75-89$ & 1 & $6,6 \%$ & Tinggi \\
\hline $60-74$ & 2 & $13,3 \%$ & Sedang \\
\hline $40-59$ & 1 & $6,6 \%$ & Rendah \\
\hline $0-39$ & 0 & $0 \%$ & Sangat Rendah \\
\hline Total & 15 & $100 \%$ & \\
\hline
\end{tabular}

Tabel 2 memperlihatkan hasil pretest sebesar 13,3\% berada pada kategori sedang, $60 \%$ berada pada kategori rendah, dan $6,6 \%$ berada pada kategori sangat rendah. Hal ini menunjukkan bahwa sebelum diajarkan materi luas bangun datar dengan model pembelajaran Treffinger, para siswa memiliki pengetahuan yang masih kurang terhadap materi luas bangun datar. Sedangkan pada Tabel 2 menunjukkan hasil Posttest sebesar $73,3 \%$ berada pada kategori sangat tinggi, 6,6\% berada pada kategori tinggi, 13,3\% berada pada kategori sedang, dan 6,6\% berada pada kategori rendah, hal ini menunjukkan bahwa adanya kemajuan siswa dalam memahami materi luas bangun datar mengalami.

Berdasakan data yang telah diperoleh terhadap hasil pretest dan posttest, klasifikasi peningkatan hasil belajar siswa dapat ditunjukkan menggunakan nilai gain ternormalisasi seperti pada Tabel 4. 
Tabel 4. Klasifikasi Peningkatan Hasil Belajar Siswa Menggunakan N-gain

\begin{tabular}{|c|c|c|c|}
\hline Interval & Jumlah Siswa & Presentase & Kategori \\
\hline $\mathrm{g} \geq 0,70$ & 11 & $73,3 \%$ & Tinggi \\
\hline $0,30 \leq \mathrm{g}<0,70$ & 3 & $20 \%$ & Sedang \\
\hline $\mathrm{g}<0,30$ & 1 & $6,6 \%$ & Rendah \\
\hline Total & 15 & $100 \%$ & \\
\hline
\end{tabular}

Berdasarkan Tabel 4 terlihat bahwa 73,3\% siswa dengan peningkatan hasil belajar matematika berada pada kategori tinggi, 20\% siswa berada pada kategori sedang, dan $6,6 \%$ siswa berada pada kategori rendah. Hal ini menunjukkan bahwa adanya peningkatan terhadap hasil belajar siswa dengan menggunakan model pembelajaran Treffinger.

\section{Uji Pengaruh Model Treffinger Terhadap Hasil Belajar}

Dapat dijelaskan bahwa sebelum dilakukan pengumpulan data hasil tes. Soal tes sudah dilakukan uji validitas dan realibilitas. Tabel 5 dan 6 menyajikan hasil pengujiannya.

Tabel 5 Hasil Uji Validitas

\begin{tabular}{|c|c|c|c|}
\hline $\begin{array}{c}\text { Nomor } \\
\text { Soal }\end{array}$ & $\begin{array}{c}\text { Pearson } \\
\text { Correlation }\end{array}$ & $\begin{array}{c}\text { Sig. (2- } \\
\text { tailed) }\end{array}$ & Keterangan \\
\hline 1 & 0,578 & 0,024 & Valid \\
\hline 2 & 0,819 & 0,000 & Valid \\
\hline 3 & 0,671 & 0,006 & Valid \\
\hline 4 & 0,872 & 0,000 & Valid \\
\hline 5 & 0,732 & 0,002 & Valid \\
\hline
\end{tabular}

Setelah melakukan uji validitas, selanjutnya peneliti melakukan uji realibilitas dengan meggunakan perhitungan SPSS 23 For Windows diperoleh hasil sebagai berikut:

Tabel 6 Hasil Uji Realibilitas

\begin{tabular}{|c|c|}
\hline Cronbach's Alpha & N of Items \\
\hline 0,532 & 3 \\
\hline
\end{tabular}

Langkah selnjutnya dilakukan uji prasyarat terkait dengan normalitas dan homogenitas data. Hasil pengujian dengan menggunakan Kolmogorov-Smirnov diperoleh data tidak berdistribusi normal karena nilai sig $(0,002)$ lebih kecil dari 0,05. Sedangkan untuk uji homogenitas dengan menggunakan Levene uji diperoleh data homogen karena nilai sig $(0,833)$ lebih besar dari 0,05. Karena salah satu syarat tidak terpenuhi maka dilakukan analisis dengan menggunakan wilcoxon test.

Sebelum dilakukan pengujian terlebih dahulu ditetapkan hipotesis penelitian sebagai berikut:

$\mathrm{H}_{0}$ : Ada pengaruh model pembelajaran Treffinger terhadap hasil belajar siswa.

$\mathrm{H}_{1}$ : Tidak ada pengaruh model pembelajaran Treffinger terhadap hasil belajar siswa.

\section{Uji t-dependent (Paired Sample T-test)}

Setelah dilakukan uji prasyarat analisis data, diketahui bahwa dari pretest dan posttest berdistribusi tidak normal dan homogen. Hasil pengujian diperoleh data tidak berdistribusi normal, maka digunakan statistik nonparametrik dengan uji Wilcoxon. Tabel 7 menampilkan hasil pengujian. 
Tabel 7. Wilcoxon Signed ranks Test

\begin{tabular}{|c|c|}
\hline Nilai & Pretest-Posttest \\
\hline $\mathrm{Z}$ & $-3,417^{D}$ \\
\hline Asymp. Significant (2-tailed) & 0,001 \\
\hline
\end{tabular}

Berdasarkan hasil uji $t$-dependent diperoleh nilai hitung $=-3,417$ dengan nilai sig. $(0,001)$ yang kurang dari 0,05 , sehingga disimpulkan terdapat perbedaan peningkatan hasil belajar siswa MI Salman Al-Farisi pada materi bangun datar sebelum dan sesudah diterapkan model pembelajaran Treffinger. Hal ini mengindikasikan ada pengaruh model pembelajaran Treffinger terhadap hasil belajar siswa.

\section{Pembahasan}

Pembelajaran matematika sangat penting untuk membentuk pola berpikir siswa secara sistematis dan logis, jadi upaya yang harus dilakukan oleh guru dalam pembelajaran matematika yaitu memotivasi, memfasilitasi, menjadi mediator, serta mengevaluasi siswa untuk dapat belajar. Hasil dari penelitian menunjukkan bahwa pembelajaran dengan menggunakan model pembelajaran Treffinger, ternyata lebih efektif dalam meningkatkan hasil belajar siswa pada materi luas bangun datar di kelas IV MI Salman Al-Farisi Liang.

Untuk melihat peningkatan hasil belajar siswa yang berdasarkan hasil perhitungan $\mathrm{N}$-gain diperoleh hasil belajar siswa dengan menggunakan model pembelajaran Treffinger $73,3 \%$ siswa dengan peningkatan hasil belajar matematika berada pada kategori tinggi, 20\% siswa berada pada kategori sedang, dan 6,6\% siswa berada pada kategori rendah.

Materi yang diajarkan dalam proses pembelajaran oleh guru menggunakan model pembelajaran Treffinger, dimana pelaksanaan dilakukan sebanyak 5 kali pertemuan yaitu 3 kali pertemuan untuk proses belajar mengajar dan 2 kali pertemuan untuk pemberian pretest dan posttest dengan menggunakan soal essay.

Untuk menjawab kedua tingkatan dari model pembelajaran Treffinger, maka peneliti membuat soal dan menghubungkannya dengan kehidupan sehari-hari. Soal yang diujikan adalah: Hana memiliki sebuah jilbab berbentuk persegi yang memiliki keliling $200 \mathrm{~cm}$ berapakah luas dari jilbab Hana?, Jawaban siswa dimulai dengan memahami masalah:

Diketahui: Keliling persegi $=200 \mathrm{~cm}$

Tingkat 1

Ditanya: Luas persegi

Pemahaman Awal

Pada saat siswa telah mampu menjawab atau menuliskan yang diketahui merupakan keliling persegi dan yang ditanya merupakan luas persegi maka siswa telah melalui tingkatan pertama yaitu pemahaman awal.

$$
\begin{aligned}
& \mathrm{K}=4 \times \mathrm{s} \\
& 80=4 \times \mathrm{s} \\
& \mathrm{s}=80 / 4=20 \\
& \mathrm{~L}=\mathrm{s} \times \mathrm{s} \\
& \quad=20 \times 20=400
\end{aligned}
$$

Jadi, luas jilbab Hana adalah $400 \mathrm{~cm}$

Tingkat 2

Proses Bekerja 
Pada saat siswa mampu mencari hasil dari sisi yang belum diketahui dengan menggunakan rumus keliling karena yang telah diketahui merupakan keliling, dan siswa mampu mencari luas persegi. Maka siswa telah melalui tingkatan kedua yaitu bekerja.

Untuk menjawab tingkatan ketiga dari model pembelajaran treffinger, maka siswa diujikan dengan soal: Ayah Zain akan menanam rumput pada taman belakang rumahnya yang berbentuk segitiga. Pada taman tersebut sisi terpanjangnya $10 \mathrm{~m}$, sedangkan sisi terpendeknya $6 \mathrm{~m}$. Misalkan harga rumput Rp. $10.000,00$ per $\mathrm{m}^{2}$, berapakah biaya yang dibutuhkan ayah Zain untuk menanam rumput pada tamannya?. Saat siswa mampu menjawab seperti pada contoh di bawah ini maka siswa telah melalui tingkatan ketiga yaitu, bekerja dengan masalah.

Diketahui: Sisi terpanjang $=10 \mathrm{~m}$

sisi terpendek $=6 \mathrm{~m}$

$$
\begin{aligned}
& \text { Ditanya: Biaya yang dibutuhkan ayah } \\
\text { Zain? } & \text { Jawab: } \\
t^{2}= & 10^{2}-6^{2} \\
t^{2}= & 100-36 \\
t^{2}= & 64 \\
t= & \sqrt{ } 64=8 \\
& \text { Langkah selanjutnya dihitung Luas } \\
& \mathrm{L}=1 / 2 \times \mathrm{a} \times \mathrm{t} \\
= & 1 / 2 \times 8 \times 6 \\
= & 1 / 2 \times 48 \\
= & 48 / 2 \\
= & 24
\end{aligned}
$$

Tingkat 3

Bekerja Dengan

Masalah

Jadi luasnya adalah $24 C^{2}$

Biaya $=24 \times 10.000=240.000$

Jadi, biaya yang butuhkan Edo adalah Rp. 240. 000,00

Respon siswa terhadap soal - soal tersebut, mereka telah mampu menjawab dengan benar dan sesuai langkah - langkah yang ada pada materi yang telah diberikan oleh penulis untuk mereka pelajari. Tiga tingkatan dari model pembelajaran Treffinger ialah, tingkat I Basic Tools (Pemahaman awal), tingkat II Practice With Process (berlatih dengan proses), tingkat III Working With Real Problems (bekerja dengan masalah).

Observasi dalam penelitian ini dilakukan dengan mengamati aktivitas guru dan siswa dalam proses pembelajaran berlangsung. Respon siswa selama proses pembelajaran berlangsung sangatlah antusias, dan siswapun juga sangat aktif dalam diskusi dan juga tanya jawab dengan guru. Siswa mengalami progres yang sangat baik secara bertahap dalam berpikir konvergen dan divergen.

Pada saat guru menyakan tentang materi yang akan dipelajari dan siswa menjawab dengan baik dan sesuai dengan pemahaman mereka, pada tahap itu siswa telah melalui tingkatan ke I dari model pembelajaran Treffinger yaitu Basic Tools (pemahaman awal). Pada saat guru memberikan contoh tentang cara menghitung luas bangun datar dan memberikan kertas origami yang berbentuk sebuah bangun datar, dan telah diketahui sisi - sisi dari bangun datar tersebut, serta melakukan tanya jawab dengan siswa mengenai kertas origami yang ditampilkan oleh guru. Siswa mampu menjawab dengan baik pertanyaan yang diberikan oleh siswa, pada tahap ini siswa telah melalui tingkatan ke II dari model pembelajaran Treffinger yaitu Practice With Procces (berlatih dengan proses).

Pada saat siswa telah mengerjakan LKS yang telah diberikan oleh guru, yang di 
dalam LKS tersebut terdapat soal yang menghubungkan materi dengan permasalahan yang terdapat dalam kehidupan siswa atau dunia nyata, dan siswa juga telah mampu menjawabnya dengan baik. Pada saat ini siswa telah melalui tingkatan ke III dari model pembelajaran Treffinger yaitu Working With Real Problems (berkerja dengan masalah).

\section{KESIMPULAN}

Dari pembahasan diatas dapat disimpilkan bahwa Model pembelajaran yang dipakai peneliti dalam penelitian ini adalah model pembelajaran Treffinger, merupakan model pembelajaran kreatif, yang melibatkan kemampuan kognitif dan afektif. Memiliki tiga tingkatan langkah - langkah pembelajaran, sehingga mendorong siswa agar lebih aktif dalam pembelajaran, dan dapat mengaplikasikannya dalam kehidupan sehari-hari. Sehingga disimpulkan bahwa:

1. Ada pengaruh model pemebelajaran Treffinger terhadap hasil belajar siswa

2. Model pembelajaran Treffinger efektif dalam meningkatkan hasil belajar siswa pada materi luas bangun datar di kelas IV MI Salman Al-Farisi Liang.

3. Siswa memberikan respon positif terhadap penggunaan model pembelajaran Treffinger

\section{DAFTAR PUSTAKA}

Abdul Gafoor, K., \& Kurukkan, A. (2015). Why High School Students Feel Mathematics Difficult? An Exploration of Affective Beliefs. Paper presented In UGC Sponsored National Seminar on Pedagogy of Teacher Education-Trends and Challenges At Farook Training College, Kozhikode, Kerala. Online (Tersedia): https://files.eric.ed.gov/fulltext/ED560266.pdf

Ajie, W. T. S., Ramalis, T. R., \& Liliawati, W. (2013). Penerapan Metode Science Literacy Circles (Slc) Untuk Meningkatkan Literasi Sains Dan Mengembangkan Karakter Siswa Smp. WaPFi (Wahana Pendidikan Fisika), 1(1), 12-17. https://doi.org/10.17509/wapfi.v1i1.4889

Azizah, M., Sulianto, J., \& Cintang, N. (2018). Analisis Keterampilan Berpikir Kritis Siswa Sekolah Dasar pada Pembelajaran Matematika Kurikulum 2013. Jurnal Penelitian PendidikanA \& A (Semarang), 35(1), 61-70. https://doi.org/10.15294/jpp.v35i1.13529

Ferdianto, F. (2015). Media Audio Visual Pada Kemampuan Komunikasi Matematis Siswa Kelas Ix. Euclid, 2(2), 306-314. https://doi.org/10.33603/e.v2i2.365

Sari, Y. I., \& Putra, D. F. (2015). Pengaruh Model Pembelajaran Treffinger terhadap Kemampuan Berpikir Kritis dan Kreatif Mahasiswa Universitas Kanjuruhan Malang. Jurnal Pendidikan Geografi, 20(2), 30-38.

Takaria, J. (2018). The Ability Of Statistical Literacy Student Teacher Candidate In Terms Of Prior-Ability On Mathematics. Jurnal Kependidikan, 2(2), 395-408.

Takaria, J., \& Talakua, M. (2018). Kemampuan Literasi Statistik Mahasiswa Calon Guru Ditinjau Dari Kemampuan Awal Matematika. Jurnal Kependidikan, 2(2), 395-408.

Takaria, J. (2019). Pemahaman Konsep Volume Bangun Ruang Melalui Hukum Kekekalan Isi (Apakah Anak Saya Sesuai Dengan Teori Piaget). Jurnal Pedagogika \& Dinamika Pendidikan, Vol 7(1), 1-11.

Wirahayu, Y. A., Purwito, H., \& Juarti, J. (2018). Penerapan Model Pembelajaran Treffinger dan Ketrampilan Berpikir Divergen Mahasiswa. Jurnal Pendidikan Geografi, 23(1), 30-40. https://doi.org/10.17977/um17v23i12018p030

Verhoeven, P. (2006). Statistics education in the Netherlands and Flanders: An outline of introductory courses at Universities and Colleges. In ICOTS-7 Conference Proceedings 